\title{
White grubs (Coleoptera, Melolonthidae) in the "Planalto Region", Rio Grande do Sul state, Brazil: Key for identification, species richness and distribution
}

\author{
Mariana A. Cherman ${ }^{1,3}$, Jerson V. C. Guedes ${ }^{1}$, Miguel A. Morón², Elder Dal Prá1 \& Maurício Bigolin ${ }^{1}$ \\ ${ }^{1}$ Departamento de Defesa Fitossanitária da Universidade Federal de Santa Maria (UFSM), 97105-900 Santa Maria-RS, Brazil. \\ marianabioar@gmail.com. \\ ${ }^{2}$ Red de Biodiversidad y Sistemática, Instituto de Ecologia, A. C., Apartado Postal 63, 91000, Xalapa, Veracruz, Mexico. \\ ${ }^{3}$ Corresponding author.
}

\begin{abstract}
White grubs (Coleoptera, Melolonthidae) in the "Planalto Region", Rio Grande do Sul state, Brazil: Key for identification, species richness and distribution. The objective of this study was to survey the occurrence and geographic distribution of white grub species (Coleoptera, Melolonthidae) in cultivated and non-cultivated fields of the "Planalto Region", Rio Grande do Sul state, Brazil and develop a key at genus-level. Twenty-eight species from 15 genera and three subfamilies were recorded: Dynastinae, Melolonthinae and Rutelinae. The species or genera recorded for the first time in the state are: Cyclocephala metrica, C. tucumana, Isonychus albicinctus, Liogenys bidenticeps, L. fusca, L. obesa and L. sinuaticeps, Paranomala violacea, as well as unidentified species of Amononyx, Dicrania, Leucothyreus, Macrodactylus, Plectris and Rhizogeniates. Among the species recorded, 23 were associated with winter crops. Only Cyclocephala metrica, Dyscinetus rugifrons, two species of Leucothyreus and one species of the tribe Sericini were not present in cultivated crop fields. Cyclocephala flavipennis and Diloboderus abderus occurred in most of the municipalities sampled, often associated with Plectris sp., C. modesta and C. putrida. The highest richness of melolonthids was concentrated in the northeast of the Planalto region.
\end{abstract}

KEYWORDS: grain crops, Insecta, rhizophagous larvae, species assemblages, taxonomy.

The "Planalto region" is one of the most important grain producing areas of Rio Grande do Sul state and is among the most important in Brazil. The most common crops are soybeans, corn and wheat, and to a lesser extent oats. These crops, together with rice, form the agricultural economic basis of the state (IBGE 2010). With the introduction of no-till methods after the 1980s, various problems associated with white grubs appeared in winter crops in the state. White grubs are beetle larvae belonging to Melolonthidae, that feed on the roots and seeds of various plants (Pereira \& Salvadori 2006). Although these melolonthid species damage various crops, there is a lack of knowledge about their biology and identification in South America compared to Central and North America (Morón 1997). Several causes limit the number of specialists who study this topic. White grubs go unnoticed in the soil until they produce some disequilibrium in the agrosystem, which results in more intensive research since economic interests are affected, such as crop yield losses. Also, there are various difficulties in studying the biology and behavior of soil dwelling insects without disturbing their natural development (Morón 2004). Due to the poor knowledge on the richness of this group, people believe that all species can be controlled in the same way. Together with monitoring, controlling is expensive and time-consuming and can lead to an incorrect pest management. Taxonomic characters used to differentiate among Melolonthidae larvae are mainly present in mouth parts and ventral part of the last abdominal segment (raster). The raster has bristles (pali) distributed in various ways according to the species and these can form one or more rows called palidia (Morón et al. 1997). Even so, identifications should be confirmed by breeding individuals to the adult stage in the laboratory, because larvae are very similar to each other (PardoLocarno et al. 2005). In Brazil, Melolonthidae have 1,008 species with soil-inhabiting larvae (Morón 2004). Species assemblages differ in composition and richness from one region to another, depending on the orography, weather and different crops of each locality (Pardo-Locarno et al. 2003). Surveys about regional species assemblages is important for developing suitable pest management programs, since the strategies adopted in one region may not necessarily be appropriate in another. The objective of the present study was to identify melolonthid larvae found in cultivated and non-cultivated fields of the Planalto region of Rio Grande do Sul, bring species records up-to-date, develop an identification key and determine their geographic distribution.

\section{MATERIAL AND METHODS}

A survey of melolonthid species (Coleoptera, Scarabaeoidea) was carried out in the Planalto region of Rio Grande do $\mathrm{Sul}$, in southern Brazil. The mean annual temperature is $18.0^{\circ} \mathrm{C}$, varying from 16.0 to $19.4^{\circ} \mathrm{C}$. Higher temperatures are observed 
in the west of the Planalto and the lowest ones in the northeast. The mean average temperature varies from 9.9 to $13.6^{\circ} \mathrm{C}$ in July and from 22.3 to $26.1^{\circ} \mathrm{C}$ in January. Values of normal rainfall in the state vary from 1,186 (eastern Planalto) to 2,468 $\mathrm{mm} /$ year (western Planalto) (Brasil 1973). The altitude varies from $140 \mathrm{~m}$ (Manoel Viana) in the east to $770 \mathrm{~m}$ (Caseiros) in the northeast. Latosol is the predominant soil type in the region, but also occur Argisol in the west (Streck et al. 2008). The Planalto is represented by the combination of two floristic ecoregions, the Brazilian Araucaria moist forests and "Campos" moist grasslands, both with secondary vegetation and agricultural activities (Duarte et al. 2006). The Brazilian Araucaria moist forests have a predominance of Araucaria angustifolia, Podocarpus lambertii and Ilex paraguariensis. "Campos" grasslands is composed mainly by Paspalum notatum and Aristida pollens, as well as species of Stipa, Andropogon and Erianthus undergrowth vegetation. Other important elements are the gallery forests, with representative species of seasonal and rainforests. They belong to different genera of Asteraceae, Cyperaceae, Poaceae, Fabaceae, Pteridophytae and Verbenaceae (Leite 2002).

Larvae were collected from 23 representative agricultural municipalities with occurrence of white grubs, as informed by farmers and extension specialists (Table I). Samples were collected during the period of highest larval populations, from July to September in both years 2009 and 2010. At each municipality, a cultivated area (CA) and a non-cultivated area (NA) were chosen, with 800 to $2000 \mathrm{~m}$ distance from each other. The cultivated area varied from wheat, oats to Italian ryegrass, while non-cultivated area was always open wild field. In each area, trenches of $50 \mathrm{~cm}$ long x $25 \mathrm{~cm}$ wide x 30 $\mathrm{cm}$ deep were opened. The number of sample points depended on the size of the sampled area, varying from 20 to 40 points. Larvae from 2 nd and 3rd instar were collected individually, placed in plastic containers containing soil from the area and transported to the Entomology Laboratory of the Federal University of Santa Maria (UFSM). The specimens were identified using taxonomic keys and larval descriptions of Melolonthidae elaborated by Frana (2003), Pereira \& Salvadori (2006) and Neita-Moreno et al. (2012). Besides the general aspects of the body, morphological characteristics used to differentiate the larvae were: color and size of the cephalic capsule, number and form of dorsal sensorial maculae of the last antennomere, distribution of bristles on the labrum and epipharynx and details of stridulatory structures in the maxilla and mandible. On the abdomen, shape of the anal opening, bristle type and organization on the ventral part of the extreme portion of the abdomen (raster), shape and size of the respiratory plates, proportions of each pair of legs and tarsungulus size. The terms utilized for each diagnostic structure are based in Böving (1936) and Ritcher (1966). All larval morphotypes collected were separated into two lots. In one lot, larvae were boiled and preserved in $70 \%$ alcohol to be used later as vouchers and for comparing with identified species. Larvae of the other lot were bred in the laboratory under controlled conditions $\left(25^{\circ} \mathrm{C}\right.$ temperature, $70 \%$ relative humidity and 12 hour photophase), to obtain adults for later taxonomic identification. The larvae were

Table I. Municipalities sampled, coordinates, previous and actual vegetation or cultivated crops, sampling date, area sampled (in hectares) and number of dug trenches (n) for cultivated and non-cultivated areas in the Planalto region of Rio Grande do Sul, southern Brazil, in 2009 and 2010.

\begin{tabular}{|c|c|c|c|c|c|c|c|c|c|c|c|c|}
\hline & \multicolumn{7}{|c|}{ Cultivated crop fields } & \multicolumn{5}{|c|}{$\begin{array}{c}\text { Non-cultivated sites } \\
\text { (mix of moist forests and open native grasslands) }\end{array}$} \\
\hline & Municipality & Coordinates & $\begin{array}{l}\text { Previous } \\
\text { crop }\end{array}$ & $\begin{array}{l}\text { Crop at time of } \\
\text { sampling }\end{array}$ & Date & $\begin{array}{c}\text { Area } \\
\text { (ha) }\end{array}$ & $\mathrm{n}$ & Municipality & Coordinates & Date & $\begin{array}{c}\text { Area } \\
\text { (ha) }\end{array}$ & $\mathrm{n}$ \\
\hline Caseiros & $28^{\circ} 15^{\prime} \mathrm{S}$ & $51^{\circ} 40^{\prime} \mathrm{W}$ & corn & fallow & 5/Aug/2010 & 3 & 25 & $28^{\circ} 15^{\prime} \mathrm{S}$ & $51^{\circ} 41^{\prime} \mathrm{W}$ & 5/Aug/2010 & 5 & 25 \\
\hline Chapada & $28^{\circ} 15^{\prime} \mathrm{S}$ & $53^{\circ} 4^{\prime} \mathrm{W}$ & soybeans & Italian ryegrass & $10 / \mathrm{Sep} / 2010$ & 4 & 25 & $28^{\circ} 15^{\prime} \mathrm{S}$ & $53^{\circ} 5^{\prime} \mathrm{W}$ & $10 / \mathrm{Sep} / 2010$ & 1 & 25 \\
\hline Coxilha & $28^{\circ} 11^{\prime} \mathrm{S}$ & $52^{\circ} 20^{\prime} \mathrm{W}$ & soybeans & oats & 10/Sep/2010 & 2 & 25 & $28^{\circ} 11^{\prime} \mathrm{S}$ & $52^{\circ} 20^{\prime} \mathrm{W}$ & $10 / \mathrm{Sep} / 2010$ & 2 & 25 \\
\hline Cruz Alta & $28^{\circ} 31^{\prime} \mathrm{S}$ & $53^{\circ} 41^{\prime} \mathrm{W}$ & soybeans & oats & 27/Aug/2009 & 21 & 43 & $28^{\circ} 32^{\prime} \mathrm{S}$ & $53^{\circ} 42^{\prime} \mathrm{W}$ & 27/Aug/2009 & 7 & 20 \\
\hline Dois Irmãos das Missões & $27^{\circ} 38^{\prime} \mathrm{S}$ & $53^{\circ} 25^{\prime} \mathrm{W}$ & soybeans & oats + Italian ryegrass & $18 / \operatorname{Sep} / 2010$ & 8 & 25 & $27^{\circ} 39^{\prime} \mathrm{S}$ & $53^{\circ} 25^{\prime} \mathrm{W}$ & $18 / \mathrm{Sep} / 2010$ & 3 & 25 \\
\hline Fortaleza dos Valos & $28^{\circ} 41^{\prime} \mathrm{S}$ & $53^{\circ} 26^{\prime} \mathrm{W}$ & soybeans & oats & 9/Sep/2010 & 5 & 25 & $28^{\circ} 40^{\prime} \mathrm{S}$ & $53^{\circ} 27^{\prime} \mathrm{W}$ & 9/Sep/2010 & 3 & 25 \\
\hline Guabiju & $28^{\circ} 33^{\prime} \mathrm{S}$ & $51^{\circ} 38^{\prime} \mathrm{W}$ & soybeans & Italian ryegrass & 6/Aug/2010 & 9 & 25 & $28^{\circ} 33^{\prime} \mathrm{S}$ & $51^{\circ} 39^{\prime} \mathrm{W}$ & 6/Aug/2010 & 2 & 25 \\
\hline Ijuí & $28^{\circ} 30^{\prime} \mathrm{S}$ & $53^{\circ} 48^{\prime} \mathrm{W}$ & soybeans & fallow & 13/Aug/2009 & 13 & 31 & $28^{\circ} 31^{\prime} \mathrm{S}$ & $53^{\circ} 47^{\prime} \mathrm{W}$ & 14/Aug/2009 & 2 & 25 \\
\hline Itaara & $29^{\circ} 32^{\prime} \mathrm{S}$ & $53^{\circ} 45^{\prime} \mathrm{W}$ & soybeans & wheat & 26/Aug/2009 & 9 & 20 & $29^{\circ} 32^{\prime} \mathrm{S}$ & $53^{\circ} 46^{\prime} \mathrm{W}$ & 26/Aug/2009 & 9 & 20 \\
\hline Lagoa Vermelha & $28^{\circ} 38^{\prime} \mathrm{S}$ & $51^{\circ} 37^{\prime} \mathrm{W}$ & soybeans & oats & $30 / \mathrm{Jul} / 2009$ & 15 & 30 & $28^{\circ} 29^{\prime} \mathrm{S}$ & $51^{\circ} 33^{\prime} \mathrm{W}$ & $30 / J u l / 2009$ & 9 & 25 \\
\hline Manoel Viana & $29^{\circ} 13^{\prime} \mathrm{S}$ & $55^{\circ} 31^{\prime} \mathrm{W}$ & sorghum & oats + Italian ryegrass & 13/Aug/2010 & 8 & 25 & $29^{\circ} 13^{\prime} \mathrm{S}$ & $55^{\circ} 31^{\prime} \mathrm{W}$ & 13/Aug/2010 & 4 & 25 \\
\hline Nonoai & $27^{\circ} 16^{\prime} \mathrm{S}$ & $52^{\circ} 43^{\prime} \mathrm{W}$ & soybeans & fallow & 21/Aug/2010 & 8 & 25 & $27^{\circ} 15^{\prime} \mathrm{S}$ & $52^{\circ} 43^{\prime} \mathrm{W}$ & 21/Aug/2009 & 2 & 25 \\
\hline Nova Palma & $29^{\circ} 17^{\prime} \mathrm{S}$ & $53^{\circ} 28^{\prime} \mathrm{W}$ & soybeans & wheat & 25/Aug/2010 & 6 & 25 & $29^{\circ} 17^{\prime} \mathrm{S}$ & $53^{\circ} 28^{\prime} \mathrm{W}$ & 25/Aug/2010 & 6 & 25 \\
\hline Panambi & $28^{\circ} 9^{\prime} \mathrm{S}$ & $53^{\circ} 27^{\prime} \mathrm{W}$ & soybeans & turnip + oats & 21/Aug/2009 & 15 & 30 & $28^{\circ} 9^{\prime} \mathrm{S}$ & $53^{\circ} 27^{\prime} \mathrm{W}$ & 21/Aug/2009 & 2 & 25 \\
\hline Porto Lucena & $27^{\circ} 50^{\prime \prime S}$ & $54^{\circ} 55^{\prime \prime} \mathrm{W}$ & soybeans & wheat & $21 / \mathrm{Aug} / 2010$ & 6 & 25 & $27^{\circ} 49^{\prime} \mathrm{S}$ & $54^{\circ} 54^{\prime} \mathrm{W}$ & 21/Aug/2010 & 5 & 25 \\
\hline Santa Rosa & $27^{\circ} 56^{\prime} \mathrm{S}$ & $54^{\circ} 32^{\prime} \mathrm{W}$ & soybeans & oats & 14/Aug/2009 & 6 & 20 & $27^{\circ} 57^{\prime} \mathrm{S}$ & $54^{\circ} 32^{\prime} \mathrm{W}$ & 14/Aug/2009 & 1.5 & 20 \\
\hline São Francisco de Assis & $29^{\circ} 18^{\prime} \mathrm{S}$ & $55^{\circ} 17^{\prime} \mathrm{W}$ & soybeans & oats & $11 / \mathrm{Jul} / 2009$ & 23 & 43 & $29^{\circ} 18^{\prime} \mathrm{S}$ & $55^{\circ} 10^{\prime} \mathrm{W}$ & 11/Jul/2009 & 4 & 28 \\
\hline São Luiz Gonzaga & $28^{\circ} 24^{\prime} \mathrm{S}$ & $54^{\circ} 56^{\prime} \mathrm{W}$ & soybeans & oats & 14/Aug/2010 & 7 & 25 & $28^{\circ} 24^{\prime} \mathrm{S}$ & $54^{\circ} 56^{\prime} \mathrm{W}$ & $14 / \mathrm{Aug} / 2010$ & 5 & 25 \\
\hline Tapejara & $29^{\circ} 04^{\prime} \mathrm{S}$ & $52^{\circ} 07^{\prime} \mathrm{W}$ & soybeans & fallow & $28 / \mathrm{Jul} / 2009$ & 5 & 39 & $28^{\circ} 3^{\prime} \mathrm{S}$ & $52^{\circ} 7^{\prime} \mathrm{W}$ & 28/Jul/2009 & 3 & 21 \\
\hline Três Palmeiras & $27^{\circ} 38^{\prime} \mathrm{S}$ & $52^{\circ} 50^{\prime} \mathrm{W}$ & soybeans & oats & 11/Sep/2010 & 3 & 25 & $27^{\circ} 38^{\prime} \mathrm{S}$ & $52^{\circ} 49^{\prime} \mathrm{W}$ & $11 / \mathrm{Sep} / 2010$ & 3 & 25 \\
\hline Tupanciretã & $28^{\circ} 54^{\prime} \mathrm{S}$ & $53^{\circ} 39^{\prime} \mathrm{W}$ & sorghum & oats + Italian ryegrass & 14/Aug/2010 & 7 & 25 & $28^{\circ} 56^{\prime} \mathrm{S}$ & $53^{\circ} 41^{\prime} \mathrm{W}$ & 14/Aug/2010 & 6 & 25 \\
\hline Vacaria & $28^{\circ} 15^{\prime} \mathrm{S}$ & $51^{\circ} 17^{\prime} \mathrm{W}$ & corn & wheat & $31 / \mathrm{Jul} / 2009$ & 9 & 35 & $28^{\circ} 15^{\prime} \mathrm{S}$ & $51^{\circ} 16^{\prime} \mathrm{W}$ & 31/Jul/2009 & 6 & 25 \\
\hline Vila Maria & $28^{\circ} 34^{\prime} \mathrm{S}$ & $52^{\circ} 7^{\prime} \mathrm{W}$ & soybeans & Italian ryegrass & 29/Jul/2009 & 5 & 36 & $28^{\circ} 34^{\prime} \mathrm{S}$ & $52^{\circ} 7^{\prime} \mathrm{W}$ & 29/Jul/2009 & 2 & 20 \\
\hline
\end{tabular}


reared in plastic containers with a substrate of soil from the area they were collected from. The soil in each container was moistened weekly during larval rearing to the adult stage. The adults obtained were killed in $70 \%$ alcohol after 15 days and mounted on entomological pins. Adult body measurements were made using a stereoscopic microscope (up to 5x) and adults were identified using keys and diagnostic descriptions for Melolonthidae in Endrödi (1985), Frey (1969), Katovich (2008) and Smith (2008). Unidentified larvae and adults were sent to Dr. Miguel Angel Morón (Instituto de Ecologia, A. C., Xalapa, Veracruz, Mexico) for identification. Vouchers were deposited in the Departamento de Defesa Fitossanitária, Federal University of Santa Maria, Rio Grande do Sul and in the Instituto de Ecología, A.C. Xalapa, Mexico. An identification key was elaborated based on the results of larvae identifications from the 23 studied municipalities.

\section{RESULTS AND DISCUSSION}

\section{Occurrence of Melolonthidae in the Planalto region of Rio Grande do Sul}

The occurrence of 28 melolonthid species were recorded from 15 genera belonging to the subfamilies Dynastinae, Melolonthinae and Rutelinae (Table II). Five of the 28 species belong to Liogenys Guerín-Meneville, 1838 (L. fusca Blanchard, 1850 (Fig. 1A), L. bidenticeps Moser, 1919; L. sinuaticeps Moser, 1918; Liogenys obesa Burmeister, 1855 and Liogenys sp.); five belong to Cyclocephala Dejean 1821 (C. flavipennis Arrow, 1914, C. modesta Burmeister, 1855, C. putrida Burmeister, 1847; C. tucumana Brèthes, 1904 (Fig. 1B) and C. metrica Steinheil, 1874(Fig. 1C)); four belong to Leucothyreus MacLeay, 1819 (Leucothyreus sp.1, Leucothyreus sp.2 (Fig. 1D), Leucothyreus sp.3 and Leucothyreus sp.4); two to Dyscinetus Harold, 1869 (D. rugifrons Burmeister, 1847 (Fig. 1E) and D. gagates Burmeister, 1847) and one species belongs to each of the genera Geniates Kirby, 1808 (Geniates sp. aff. cylindricus (Fig. 1F)); Rhizogeniates Ohaus, 1909 (Rhizogeniates sp. (Fig. 1G)); Dicrania Le Peletier and Audinet-Serville, 1828 (Dicrania sp. (Fig. 1H)); Demodema Blanchard, 1850 (D. brevitarsis (Blanchard, 1850), Macrodactylus Dejean, 1821 (Macrodactylus sp. (Fig. 1I)), Plectris Le Peletier and Audinet-Serville, 1828 (Plectris sp.), Isonychus Mannerheim, 1829 (I. albicinctus (Mannerheim, 1829) (Fig. 1J)); Amononyx Saylor, 1940 (Anomonyx sp. (Fig. 1K)); Paranomala Casey, 1915 (P. violacea Burmeister 1844 (Fig. 1L)); Diloboderus Reiche, 1859 (D. abderus Burmeister, 1826) and Phyllophaga Harris, 1827 (P. triticophaga Salvadori \& Morón, 1998). One species was identified only to tribal level, being included in the tribe Sericini (Melolonthinae).

Only 12 of the 28 species were identified in the larval stage, demonstrating the lack of descriptions and keys for the identification of immature Melolonthidae. Six of the species identified in this study have already been recorded from Brazil associated with economically important crops.
Table II. Taxonomic composition of Melolonthidae (Coleoptera) and occurrence in cultivated and non-cultivated areas of the Planalto Region of Rio Grande do Sul, southern Brazil, in 2009 and 2010. Taxa marked with an asterisk were not found in areas under agriculture.

Dynastinae (3 genera/8 species)

\begin{tabular}{|c|c|}
\hline \multirow[t]{7}{*}{ Cyclocephalini } & Cyclocephala flavipennis \\
\hline & C. modesta \\
\hline & C. putrida \\
\hline & C. tucumana \\
\hline & C. metrica* \\
\hline & Dyscinetus rugifrons* \\
\hline & D. gagates \\
\hline Pentodontini & Diloboderus. abderus \\
\hline \multicolumn{2}{|c|}{ Melolonthinae ( 8 genera/13 species) } \\
\hline \multirow[t]{5}{*}{ Diplotaxini } & Liogenys fusca \\
\hline & L. bidenticeps \\
\hline & L. sinuaticeps \\
\hline & L. obesa \\
\hline & Liogenys sp. \\
\hline \multirow[t]{6}{*}{ Macrodactylini } & Demodema brevitarsis \\
\hline & Isonychus albicinctus \\
\hline & Macrodactylus sp. \\
\hline & Plectris sp. \\
\hline & Anomonyx sp. \\
\hline & Dicrania sp. \\
\hline Melolonthini & Phyllophaga triticophaga \\
\hline Sericini & unidentified genus* \\
\hline \multicolumn{2}{|c|}{ Rutelinae (4 genera/7 species) } \\
\hline Anomalini & Paranomala violacea \\
\hline \multirow[t]{6}{*}{ Geniatini } & Geniates aff. cylindricus \\
\hline & Rhizogeniates sp. \\
\hline & Leucothyreus sp. 1 \\
\hline & Leucothyreus sp. 2* \\
\hline & Leucothyreus sp. 3* \\
\hline & Leucothyreus sp. 4 \\
\hline
\end{tabular}

Cyclocephala flavipennis, Diloboderus abderus, Demodema brevitarsis and Phyllophaga triticophaga were recorded from winter crops in different localities of Rio Grande do Sul (Salvadori \& Silva 2004). Isonychus albicinctus was recorded from Minas Gerais in eucalyptus plantations by Freitas et al. (2002). Liogenys fusca occurs in the western region of central Brazil and attacks corn and soybeans (Santos et al. 2008; Costa et al. 2009).

All 28 species were found in non-cultivated areas whereas 23 of them also occurred in cultivated areas (Table II). The predominant subfamilies in South America are Melolonthinae and Dynastinae, principally due to the richness of Plectris and Cyclocephala, respectively (Morón 1996). However, Melolonthinae was predominant in this study, with 8 genera and 13 species, with Liogenys being the richest genus (Table II). Since no adults of Plectris were collected, it is uncertain if the larvae found belong to the same species or not. Most species of the Melolonthinae are rhizophagous, with Phyllophaga being the most economically important in agriculture (King 1984).

Cyclocephala had the major richness among the Dynastinae and Leucothyreus was the richest among the Rutelinae collected. The high specific richness of a genus 
suggests that at local and regional levels there might be a delicate equilibrium in the rhizosphere, which permits interspecific coexistence. If one of these species becomes a pest, it is almost certainly due to the slow or sudden elimination of this underground richness, probably caused by monoculture or by indiscriminate application of toxic products, among other factors (Morón 1996).

\section{Key to the genera of Melolonthidae present in Rio Grande} do Sul, Brazil, based on 3rd instar larvae

1. Anal opening transverse (Fig. 2N), straight or slightly curved. Last antennomere with one or more dorsal maculae. Raster with or without defined palidia. Mandibles with a ventral stridulatory area

1'. Anal opening "V-shaped" or "Y-shaped" (Fig. 2O). Raster always with defined palidia. Last antennomere with only one dorsal macula. Mandibles without ventral stridulatory area ............................................. Melolonthinae ...... 2

2. Raster without a defined septula. Oblique palidia, which converge to the midline (Fig. 2P) ...

\section{Liogenys Guérin-Méneville}

2'. Raster with a defined septula between straight or curved, longitudinal palidia (Fig. 2Q-W)

3. Palidia with simple pali, clearly separated from the base. Respiratory plates completely or incompletely surrounding the bulla (Fig. 2C, D) ...

3'. Palidia with pali strongly close together, sometimes double and united at their base (Fig 2R, S). Respiratory plates incompletely surrounding the bulla....

4. Maximum body length greater than $8 \mathrm{~mm}$. Palidia long with more than five pali (Fig. 2Q). Respiratory plates completely surrounding the bulla ................................ 5

4'. Maximum body length less than $8 \mathrm{~mm}$. Palidia short with two to five pali, septula narrow. Respiratory plates incompletely surrounding the bulla ..... Macrodactylus Dejean

5. Epipharynx's haptomerum with four strong, welldifferentiated heli (spines on the surface). Tarsungulus of all legs with claws of the same length (Fig. 2M)

Isonychus Mannerheim

5'. Epipharynx's haptomerum with five or more heli. Claws of meso- and metatarsungulus shorter than the protarsungulus (Fig. 2L) Phyllophaga Harris

6. Respiratory plates with the same diameter in all segments (Fig. 2B). Haptomerum roundish with five heli. Claws of protarsungulus more developed than in the other pairs of legs ........................................... Demodema Blanchard

6'. Respiratory plates becoming progressively smaller in the posterior segments (Fig. 2A). Claws of all the tarsungulus poorly developed

7. Palidia recurved, convergent at ends, pali closed together (Fig. 2R) Dicrania Serville

7'. Palidia parallel in the anterior half and very divergent in the posterior half (Fig. 2S-U)
8. Palidia with more than one palus united at their base, divergent with the pali nearby and do not continuing to the ventral, anal labium (Fig. 2S) ......... Plectris Serville

8 '. Palidia with simple pali, divergent in the posterior half, at the edge of the ventral, anal labium (Fig. 2U) .... Anomonyx Saylor

9. Epipharinx's plegmatia (lateral sides grooved) absent (Fig. 2J, K), heli absent, without palidia, bristles disposed in regular or irregular manner .............. Dynastinae ...... 10

9'. Epipharinx's plegmatia present (Fig. 2H, I), two to four heli, frequently with palidia formed by two rows of longitudinal, parallel pali ................. Rutelinae ......... 12

10. Haptomerum prominent, entire (Fig. 2K). Without palidia ........................................................................ 11

10'. Haptomerum prominent, with a cleft (Fig. 2J). With or without palidia Cyclocephala Dejean

11. Last antennomere with two sensorial macula (Fig. 2E) Dyscinetus Harold

11'. Last antennomere with eight dorsal, sensorial macula (Fig. 2F) Diloboderus Reiche

12. Haptomerum angled without row of heli (Fig. 2I) .... 13

12'. Haptomerum rounded with row of four heli (Fig. 2H)

Paranomala Casey

13. Palidia present, parallel, bristles around the palidia present

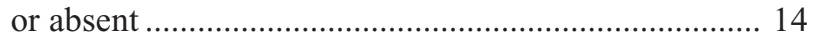

13'. Palidia absent (Fig 1N), bristles present, short and thick, disposed regularly on raster ........... Rhizogeniates Ohaus

14. Haptomerum cleft. Palidia formed by eight to nine pali (Fig. 2W) ................................. Leucothyreus MacLeay 14'. Haptomerum entire. Palidia formed by four to five pali (Fig. 2V). Geniates Kirby

\section{Distribution of species of Melolonthidae in the Planalto Region of Rio Grande do Sul}

Melolonthidae larvae were found at all the municipalities sampled. Among the 28 species of white grubs recorded, Cyclocephala flavipennis, Diloboderus abderus, Plectris sp., C. modesta and C. putrida were collected in the majority of municipalities sampled, occurring in 18, 17, 10, 9 and 8 localities, respectively (Fig. 3). A second assemblage of species occurred in four to seven localities. It is represented by Macrodactylus sp., Dyscinetus gagates (four localities), Phyllophaga triticophaga, Leucothyreus sp. 1 (five localities), Isonychus albicinctus, C. tucumana (six localities) Paranomala violacea and Geniates sp. (seven localities). Only two species were recorded in three localities, Rhizogeniates sp. and Anomonyx sp. The species Leucothyreus sp.2, Liogenys sp., L. fusca, L. bidenticeps, Dicrania sp., and $C$. metrica occurred only in two localities. Dyscinetus rugifrons, Demodema brevitarsis, Liogenys obesa, L. sinuaticeps, Leucothyreus sp.3, Leucothyreus sp.4 and the unidentified species of Sericini were each one recorded only at a single locality: Tapejara, Santa Rosa, São 

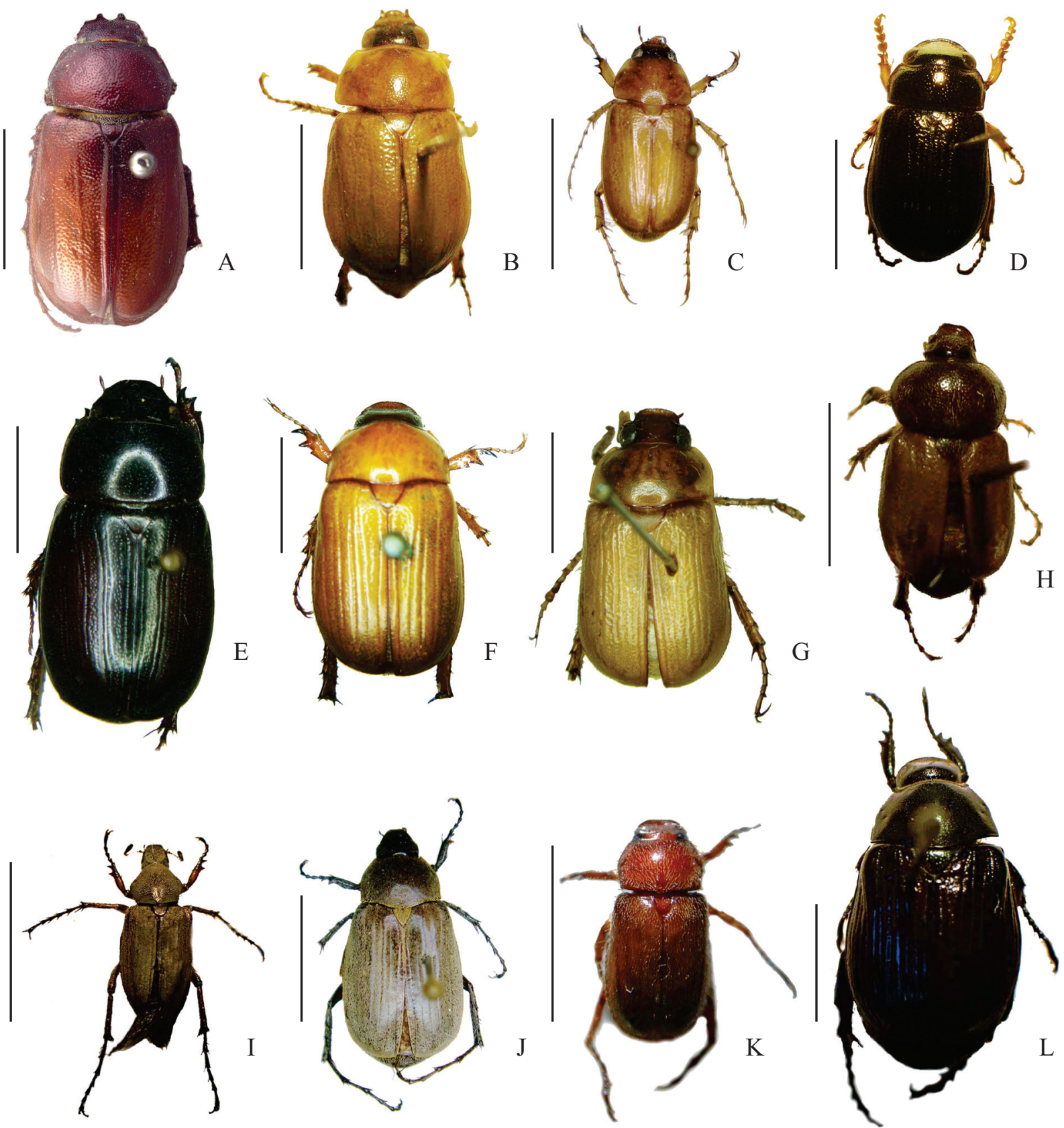

Fig. 1. Adults of species reared in the laboratory. Liogenys fusca (A), Cyclocephala tucumana (B), C. metrica (C), Leucothyreus sp.2 (D); Dyscinetus rugifrons (E), Geniates sp. (F), Rhizogeniates sp. (G), Dicrania sp. (H), Macrodactylus sp. (I), Isonychus albicinctus. (J), Anomonyx sp. (K), Paranomala violacea $(\mathrm{L})$. Scale bar, $5 \mathrm{~mm}$.

Luiz Gonzaga, Manoel Viana, Caseiros, Porto Lucena and Chapada, respectively.

The occurrence of a species in a higher number of localities could indicate a greater capacity to adapt to soil and climate conditions, as verified for Cyclocephala flavipennis and Diloboderus abderus (Pereira \& Salvadori 2006). Salvadori and Pereira (2006) reported that D. abderus is widely distributed in Rio Grande do Sul, but P. triticophaga only occurs in some areas of the northeastern and northern Planalto. Municipalities with major richness of melolonthid species were Caseiros with 13, Vila Maria with 10, Guabiju and Três
Palmeiras with nine and Nova Palma with seven species. Most municipalities showed an intermediate richness: Ijuí, Manoel Viana, Panambi, Tapejara and Vacaria with six species each and Coxilha, Cruz Alta, Dois Irmãos das Missões, Itaara, Lagoa Vermelha, São Luiz Gonzaga and Tupanciretã with five species each. The lowest richness (two species) was registered in Nonoai, followed by Chapada, Porto Lucena and Santa Rosa, with three species each. The regional richness is heterogeneous since the localities sampled varied in number of species and composition, with larger assemblages in the northeast, corresponding to Campos de Cima da Serra sub-division and the 

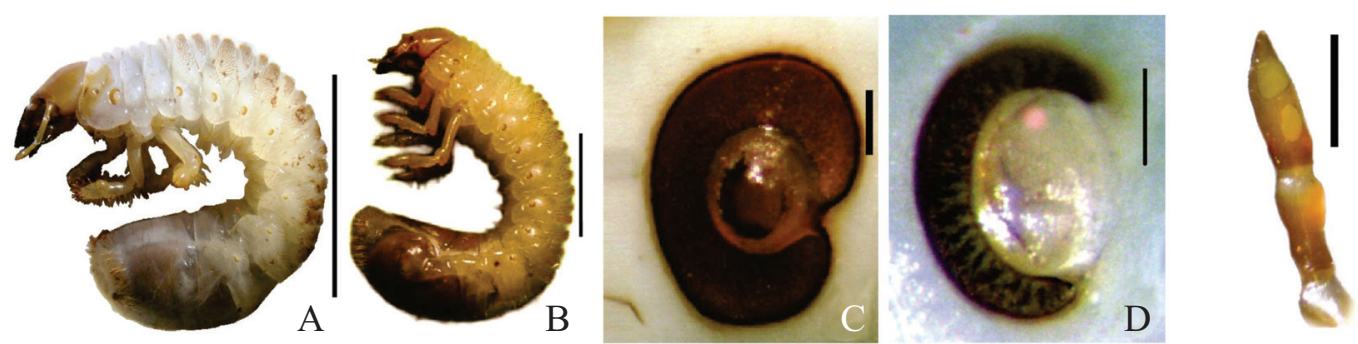

$\mathrm{E}$
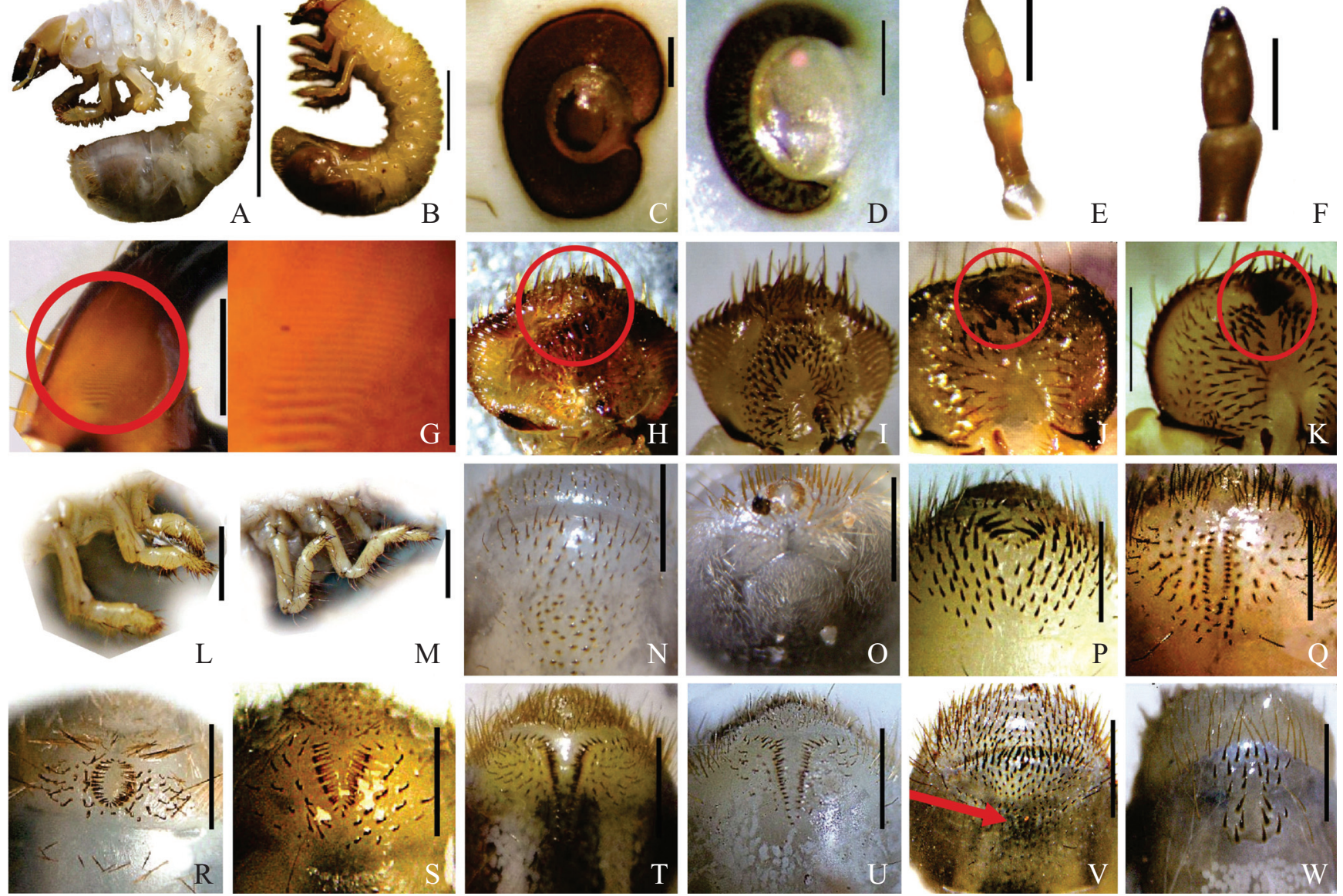

Fig. 2. Diagnostic structures used in the identification key. Size of respiratory plates of Dicrania (A) and Demodema (B). Bulla of the spiracles, complete (C) and incomplete (D). Sensorial macula of the last antennomere (E, F). Mandibula with stridulatory area (G). Epipharynx showing haptomerum (H-K) and plegmatia (H, I). Tarsal claws (L,M). Anal opening transverse (N) and V or Y-shaped (O). Raster with different types of palidia (P-W). Scale bars: (A-B) $10 \mathrm{~mm},(\mathrm{C}-\mathrm{D}) 0.5 \mathrm{~mm},(\mathrm{G}-\mathrm{K}) 1 \mathrm{~mm},(\mathrm{P}-\mathrm{W}) 3 \mathrm{~mm}$.

southern and eastern Planalto Médio sub-division. The northwest was the poorest sub-region in number of species. According to Morón (2001), who evaluated melolonthid diversity in Mexico, the regional richness pattern depends on the soil type, mean temperature and rainfall of each region.

The present study showed a trend to find a higher number of species in wetter and colder sub-regions of the state. These species would be adapted to a lower climatic variability and, therefore, would clearly prefer moist soil conditions for oviposition compared to endemic species adapted to variable regimes, which would be able to oviposit in soil areas with more variable water content (Ward \& Rogers 2007). Latosols occupy most of Rio Grande do Sul (Streck et al. 2008) and, thus, species diversity would not be conditioned by this variable. In Australia, some species of the sugarcane white grub complex (Coleoptera, Melolonthinae), for example, Dermolepida albohirtum Waterhouse, Holotrichia reynaudi Blanchard and $H$. serrata $(\mathrm{F}$.) are found preferentially in soils in the same geographic region with different levels of clay. These distribution patterns are, therefore, dependent on limiting environmental factors for oviposition and/ or mortality of eggs and larvae (Ward \& Rogers 2007). In the Planalto of Rio Grande do Sul, besides the clay content, other variables need to be investigated, such as host plants, cultivation systems, concentrations of organic matter, altitude, competition, and natural enemies, among others.

In this survey, the composition of species assemblages varied from one municipality to another. The five most common species, as showed in Fig. 3 (Cyclocephala flavipennis, Diloboderus abderus, Plectris sp., C. modesta and $C$. putrida), were only recorded together in Caseiros municipality, whereas species combinations varied in the other municipalities. Cyclocephala flavipennis and Diloboderus abderus occurred together at 12 localities, confirming their wide geographic and ecological distribution in the state, and consequently, the capacity to adapt to changes caused by agriculture and deforestation. Therefore, their occurrence together demands correct larval identification during monitoring to avoid inadequate management and crop infestations, since Cyclocephala flavipennis do not cause economic loses even with 100 larvae per square meter (Pereira \& Salvadori 2006). Although Phyllophaga triticophaga is one of the most important pest species in Rio Grande do Sul (Salvadori \& Pereira 2006), it was not widely distributed and occurred in 


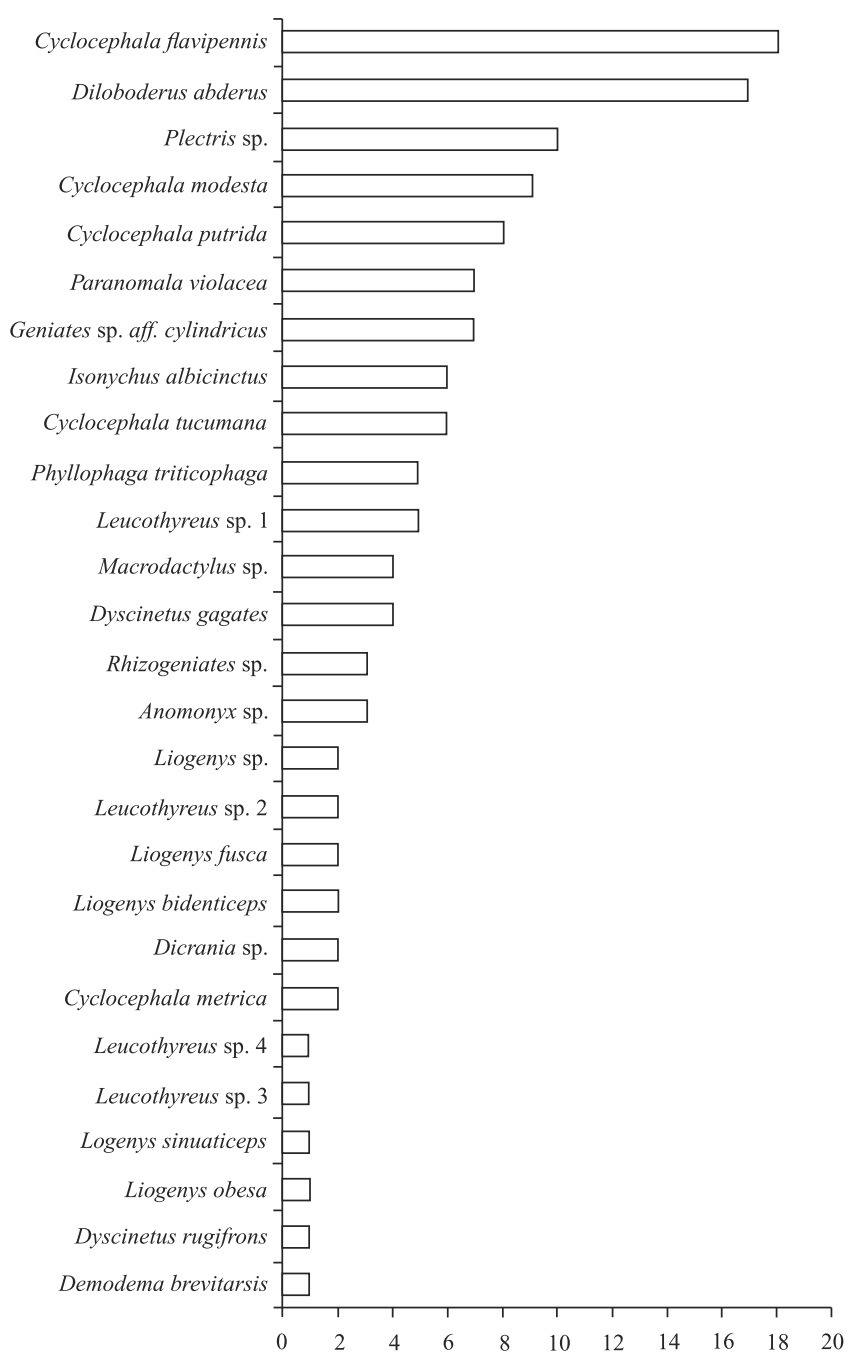

Fig. 3. Melolonthid species and number of municipalities that each one occurs in Rio Grande do Sul Planalto region, in 2009 and 2010.

only five localities. Isonychus albicinctus, collected from six localities, could be easily confused with Phyllophaga in the larval stage, but its occurrence in Rio Grande do Sul is poorly documented. Therefore, a correct identification of the larva during the monitoring of an area is indispensable for avoiding unnecessary white grub control.

The five species of Liogenys were distributed between Caseiros, Chapada, Cruz Alta, Ijuí, Manoel Viana, São Francisco de Assis and São Luiz Gonzaga municipalities. The only species known as an important pest is L. fusca (Santos et al. 2008; Costa et al. 2009) but it supposedly does not cause damage to crops in the Planalto region (Cherman et al. 2011). Thus, high richness of Liogenys observed in the present survey means that studies on biology and feeding habits of this group is necessary, to avoid an increase in the population of rhizophagous species which could be potential pests. The distribution and ecology of the species recorded from one to four localities is poorly described in the literature, except for Demodema brevitarsis. Although this species was found only in the Tapejara municipality, it is known to cause damage to both winter and summer grain crops, apparently due to its irregular biological cycle, currently under study by the EMBRAPA Wheat Centre (Morón \& Salvadori 2006).

In view of the results discussed, it is recommended that the methods for breeding and studying the biology of species, especially of Plectris, Macrodactylus and Liogenys, the most diverse genus, should be improved, considering the rhizophagous habits of their larvae. The similarity between larvae of Isonychus and Phyllophaga in the studied area demands more detailed taxonomic and biological studies since the former genus has become a pest in Minas Gerais, in southeastern Brazil.

\section{ACKNOWLEDGEMENTS}

To Dr. Paschoal Coelho Grossi (UFPR) for confirmation of some species identifications. To EMBRAPA (Empresa Brasileira de Pesquisa Agropecuária) staff and the farm owners for granting access to study sites. To CNPq (Conselho Nacional de Desenvolvimento Científico e Tecnológico) and CAPES (Coordenação de Aperfeiçoamento de Pessoal de Nivel Superior) for providing scholarships.

\section{REFERENCES}

Böving, A.G. 1936. Description of the larva of Plectris aliena Chapin and explanation of new terms applied to the epipharynx and raster. Proceedings of the Entomological Society of Washington 38: 169-185.

Brasil. 1973. Levantamento de reconhecimento dos solos do Rio Grande do Sul. Recife, Ministério da Agricultura-DNPEA-DPP. Boletim Técnico $30,431 \mathrm{p}$.

Cherman, M.A., Guedes, J.V.C., Morón, M.A., Dal Prá, E., Perini, C.R. \& Jung, A.H. 2011. First record of species of Liogenys (Coleoptera, Melolonthidae) associated with winter grain crops in Rio Grande do Sul (Brazil). Revista Brasileira de Entomologia 55: 618-620.

Costa, R.B. da, Fernandes, P.M., Oliveira, F.S., Rocha, M.R. da, Morón, M.A. \& Oliveira, L.J. 2009. Captura de adultos de Liogenys fuscus (Coleoptera: Melolonthidae) com armadilha luminosa em área sob sistema de plantio direto. Bioscience Journal 25: 1-8.

CRIA. 2001. SpeciesLink, dados e ferramentas. Campinas: Centro de Referência em Informação Ambiental. Available at: http:// splink.cria.org.br/tools?criaLANG = pt (accessed 20 March 2009).

Duarte, L.D.S., Santos, M.M.G., Hartz, S.M. \& Pillar, V.D. 2006. Role of nurse plants in Araucaria Forest expansion over grassland in south Brazil. Austral Ecology 31: 520-528.

Endrödi, S. 1985. The Dynastinae of the World. Dordrecht, Dr. W. Junk Publisher, $800 \mathrm{p}$.

Frana, J.E. 2003. Clave para la identificación de larvas de Scarabaeidae que habitan el suelo de la región central de Santa Fe. Available at: http://rafaela.inta.gov.ar/publicaciones/clave_gusano_blanco.pdf (accessed 10 April 2009).

Freitas, F.A., Zanuncio, T.V., Lacerda, M.C. \& Zanuncio, J.C. 2002. Fauna de Coleoptera coletada com armadilhas luminosas em plantio de Eucalyptus grandis em Santa Bárbara, Minas Gerais. Revista Árvore 26: $505-511$.

Frey, G. 1969. Betimmumgstabelle und Revision der Gattung Liogenys Guérrez. (Coleoptera-Melolonthinae-Macrodactylini). Entomologische Arbeiten aus dem Museum G. Frey 20: 36-64.

Instituto brasileiro de Geografia e Estatística. Pesquisa agrícola municipal (IBGE/PAM). 2010. Available at: www.sidra.ibge.gov.br/bda/pesquisas/pam/default.asp. (accessed 23 July 2010). 
Katovich, K. 2008. A generic-level phylogenetic review of the Macrodactylini (Coleoptera: Scarabaeidae: Melolonthinae). Insecta Mundi 23: 1-78.

King, A.B.S. 1984. Biology and identification of white grubs (Phyllophaga) of economic importance in Central America. Tropical Pest Management 30: 36-50.

Leite, P.F. 2002. Contribuição ao conhecimento fitoecológico do sul do Brasil. Ciência \& Ambiente 24: 51-73.

Morón, M.A. 1996. Diagnóstico y taxonomía de Phyllophaga spp. (Coleoptera: Melolonthidae) en Centroamérica, p. 62-73. In: Shannon P.J. \& Carballo, M. (eds.). Biología y control de Phyllophaga spp. Turrialba, CATIE, $132 \mathrm{p}$.

Morón, M.A. 1997. White grubs (Coleoptera: Melolonthidae: Phyllophaga Harris) in Mexico and Central America. A brief review. Trends in Entomology 1: 117-128.

Morón, M.A. 2001. Larvas de escarabajos del suelo en México (Coleoptera: Melolonthidae). Acta Zoológica Mexicana (n.s.) 1: 111-130.

Morón, M. A. 2004. Insetos de solo, p.41-68. In: Salvadori, J.R.; Ávila C. J. \& Silva, M. T.B. (eds.), Pragas de solo no Brasil. Passo Fundo: Embrapa Trigo; Dourados: Embrapa Agropecuária Oeste; Cruz Alta: Fundacep Fecotrigo, xi+541 p.

Morón, M.A. \& Salvadori, J.R. 2006. The third-stage larva and pupa of Demodema brevitarsis (Blanchard) (Coleoptera:Scarabaeidae: Melolonthinae) from southern Brazil. Proceedings of the Entomological Society of Washington 108: 511-518.

Morón, M.A., Ratcliffe, B.C. \& Deloya, C. 1997. Atlas de los escarabajos de México. Coleoptera Lamellicornia 1. Familia Melolonthidae. Comisión Nacional para el conocimiento y uso de la Biodiversidad: Sociedad Mexicana de Entomología, México, xvi+280 p.

Neita-Moreno, J.C., Morón, M.A. \& Zuluaga-Correa, C.A. 2012. Description of the immature stages of four species of Macrodactylini (Coleoptera: Melolonthidae: Melolonthinae). Neotropical Entomology 41: 150-162

Pardo-Locarno, L., Montoya-Lerma, C. \& van Schoonhoven, A. 2003. Abundancia de chisas rizofagas (Coleoptera: Melolonthidae) en agroecosistemas de Caldono y Buenos Aires, Cauca, Colombia. Revista Colombiana de Entomologia 29: 177-184.

Pardo-Locarno, L.C., Montoya-Lerma, J., Bellotti, A.C. \& von Schoonhoven, A. 2005. Structure and composition of the white grub complex (Coleoptera: Scarabaeidae) in agroecological systems of northern Cauca, Colombia. Florida Entomologist 88: 355-363.

Pereira, P.R.V.S. \& Salvadori, J.R. 2006. Guia para identificação de corós rizófagos (Coleoptera:Scarabaeoidea: Melolonthidae) comumente encontrados em cereais de inverno, milho e soja no norte do Rio Grande do Sul. Available at: http://www.cnpt.embrapa.br/biblio/co/ p_co204.pdf (accessed 15 April 2009).

Ritcher, P.O. 1966. White grubs and their allies: A study of North American scarabaeoid larvae. Corvallis, Oregon State University Press, $219 \mathrm{p}$.

Salvadori, J.R. \& Pereira, P.R.V.S. 2006. Manejo integrado de corós em trigo e culturas associadas. Available at: http://www.cnpt.embrapa.br/ biblio/co/p_co203.pdf (accessed 1 December 2009).

Salvadori, J.R. \& Silva, M.T.B. 2004. Coró-do-trigo, p. 211-232. In: Salvadori, J.R., Ávila, C. J. \& Silva, M.T. (Eds.), Pragas de solo no Brasil. Passo Fundo: Embrapa Trigo; Dourados: Embrapa Agropecuária Oeste; Cruz Alta: Fundacep Fecotrigo, xi+541 p.

Santos, A.C., Bueno, A.F., Bueno, R.C.O.F. \& Vieira, S.S. 2008. Chemical control of white grub Liogenys fuscus (Blanchard 1851) (Coleoptera: Melolonthidae) in cornfields. BioAssay 3 Available at: http//:www. bioassay. org.br/articles/3.5 (accessed 22 October 2009).

Smith, A.B.T. 2008. South American Melolonthinae (Coleoptera: Scarabaeidae) classification and nomenclature: some problems and solutions. Insecta Mundi 60: 1-28.

Streck, E.V., Kämpf, N., Dalmolin, R.S.D., Klamt, E., Nascimento P.C., Schneider, P., Giasson, E. \& Pinto, L.F.S. 2008. Solos do Rio Grande do Sul. 2nd ed. Porto Alegre, EMATER/RS, 222 p.

Ward, A.L. \& Rogers, D.J. 2007. Oviposition response of scarabaeids: Does 'mother know best' about rainfall variability and soil moisture? Physiological Entomology 32: 357-366. 